\title{
Job related mortality risks of Hanford workers and their relation to cancer effects of measured doses of external radiation
}

\author{
G W KNEALE, T F MANCUSO, AND ALICE M STEWART \\ From the Cancer Epidemiology Research Unit, Department of Social Medicine, University of Birmingham, \\ Edgbaston, Birmingham B15 2TH, UK
}

\begin{abstract}
This paper continues the series by Mancuso, Stewart, and Kneale (MSK) on studies of cancer risks for radiation workers at Hanford. It concentrates on the statistical problems posed by the need to estimate and control for job related mortality risks when there are several changes of occupation and no certainty about how different occupations are related to two socioeconomic factors which have strong health associations-namely, education and income. The final conclusion is that for tissues which are sensitive to cancer induced by radiation there is a risk of cancer for Hanford exposures whose dose response is curvilinear with long latency and increasing effect with increasing exposure age.
\end{abstract}

Analyses of Hanford data by Mancuso, Stewart, and Kneale (MSK) have aroused much controversy by insisting that the risk of cancer per unit dose of radiation is significantly higher than ICRP 26 recommendations..$^{1-5}$ Other investigators have reported negative findings for Hanford workers. ${ }^{6-8}$ Mancuso et al, however, are insisting that this is merely the result of using an inappropriate classification of the deaths from cancer, and that it needs only a regrouping of the deaths according to ICRP publication $14^{9}$ to bring all supposedly negative findings into line with MSK findings for cancers of radiosensitive tissues (table 1).

According to MSK these (A) cancers have a significantly high dose compared with non-cancer deaths and a residual group of (B) cancers have a significantly low dose. These are genuine differences since they remain even after control for a wide range of factors in a Mantel-Haenszel analysis, ${ }^{24}$ and are also a feature of other analyses of Hanford data (see table 1). Furthermore, the radiation dose for (A) cancers is significantly lower than the dose for survivors, and this difference remained until four levels of radiation monitoring of individual workers were added to the usual controlling factors. ${ }^{4}$

More recent work has shown that the monitoring data for individual workers can be used to separate

Received 17 August 1982

Accepted 14 October 1982 safe from dangerous occupations (table 2), and census code numbers (attached to each job title) can be

Table 1 Effect of reclassifying the cancers included in the analysis of Hanford data by Hutchison et al

\begin{tabular}{llll}
\hline $\begin{array}{l}\text { Dose level } \\
\text { (rads) }\end{array}$ & Deaths & \multicolumn{1}{l}{$\begin{array}{l}\text { Ratio } \\
\text { O:E }\end{array}$} \\
\cline { 2 - 3 } & Observed & Expected & \\
\hline All cancers & (ICD Nos $180-209)$ & & \\
$0.01-$ & 121 & 145.7 & 0.83 \\
$0.25-$ & 126 & 112.0 & 1.13 \\
$0.65-$ & 59 & 54.8 & 1.08 \\
$1.05-$ & 99 & 96.7 & 1.02 \\
$4.05-$ & 24 & 22.1 & 1.09 \\
$>10.05$ & 20 & 17.5 & 1.14 \\
Total & 449 & 449.0 & -
\end{tabular}

All cancers of radiosensitive tissue ${ }^{*}$ (ICD Nos 151, 153, 157, 162, 163, 200-209)

$\begin{array}{crrr}0.01- & 72 & 91 \cdot 2 & 0.79 \\ 0.25- & 77 & 69.9 & 1.10 \\ 0.65- & 35 & 34.6 & 1.01 \\ 1.05- & 67 & 62.4 & 1.07 \\ 4.05- & 18 & 14.4 & 1.24 \\ >10.05 & 15 & 11.4 & 1.32 \\ \text { Total } & 284 & 284.0 & -\end{array}$

Other cancers (ICD Nos 140-149, 154-156, 185-199)

\begin{tabular}{crrl}
$0.01-$ & 49 & $54 \cdot 7$ & 0.90 \\
$0.25-$ & 49 & 42.1 & $1 \cdot 16$ \\
$0.65-$ & 24 & 20.2 & 1.19 \\
$1.05-$ & 32 & 34.3 & 0.93 \\
$4.05-$ & 6 & 7.7 & 0.78 \\
$>10.05$ & 5 & 6.1 & 0.82 \\
Total & 165 & 165.1 & - \\
\hline
\end{tabular}

*See ICRP $14 .{ }^{\text {* }}$

9 
Table 2 Hanford occupations: types of radiation monitoring and methods of scoring for individuals and occupations

\begin{tabular}{llll}
\hline Danger levels & Types of monitoring & Annual monitoring score \\
\cline { 3 - 3 } & & $\begin{array}{l}\text { Individual } \\
\text { workers }\end{array}$ \\
\hline 1 & & \multicolumn{1}{c}{ Occupations* } \\
2 & Film badge only & 1 & 2 \\
3 & Film badge and routine urine tests & 3 & $2 \cdot 0-2 \cdot 4$ \\
4 & Repeat urine tests & 4 & $2 \cdot 9-3 \cdot 0$ \\
\hline
\end{tabular}

*Average monitoring score for all workers representing a given occupation in a given year.

Table 3 Radiation doses and mortality risks for Hanford occupations and later years.

\begin{tabular}{|c|c|c|c|c|c|}
\hline $\begin{array}{l}\text { Hanford } \\
\text { occupations }\end{array}$ & $\begin{array}{l}\text { Danger } \\
\text { levels }\end{array}$ & Man-years & $\begin{array}{l}\text { Monitoring scores* } \\
\text { (means) }\end{array}$ & $\begin{array}{l}\text { Measured doses of } \\
\text { external radiation } \\
\text { ¿Man Rems }\end{array}$ & $\begin{array}{l}\text { Differential mortality } \\
\text { scores } \dagger\end{array}$ \\
\hline $\begin{array}{l}\text { Professional and } \\
\text { technical }\end{array}$ & $\begin{array}{l}1 \\
2 \\
3 \\
4\end{array}$ & $\begin{array}{ll}26 & 861 \\
27 & 208 \\
25 & 584 \\
23 & 754\end{array}$ & $\begin{array}{l}1.92 \\
2.74 \\
3.08 \\
3.69\end{array}$ & $\begin{array}{r}2342 \\
4568 \\
6642 \\
15181\end{array}$ & $\begin{array}{l}228 \\
-\quad 210 \\
-\quad 222 \\
-\quad 29\end{array}$ \\
\hline Clerical & 1 & 47598 & $2 \cdot 03$ & 1742 & +92 \\
\hline $\begin{array}{l}\text { Operatives and } \\
\text { other manual }\end{array}$ & $\begin{array}{l}1 \\
2 \\
3 \\
4\end{array}$ & $\begin{array}{ll}34 & 529 \\
27 & 001 \\
23 & 167 \\
33 & 828\end{array}$ & $\begin{array}{l}2.28 \\
2.76 \\
3.20 \\
3.60\end{array}$ & $\begin{array}{r}2089 \\
3394 \\
3839 \\
28118\end{array}$ & $\begin{array}{l}+\quad 65 \\
+\quad 82 \\
-\quad 43 \\
-\quad 35\end{array}$ \\
\hline Not recorded & - & 19825 & $2 \cdot 56$ & 2369 & -31 \\
\hline Post Hanford & - & 661165 & - & 0 & +18 \\
\hline Total & - & 950520 & - & 70284 & 0 \\
\hline
\end{tabular}

* See table 2.

$\dagger$ These indices of general mortality measure the change in logit probability $\left(\times 10^{4}\right)$ of the annual death rate being higher $(+)$ or lower $(-)$ than the average for all workers (with control for age, sex, and calendar year).

used to separate work which requires professional or technical qualifications from lower grades of work, also clerical from non-clerical work. ${ }^{10}$ By combining the occupational and monitoring data, over 8000 job titles were eventually fitted into nine occupational groups preparatory to obtaining exact estimates of job related mortality risks.

The statistical theory behind this exact method is described in the appendix. The aim is to measure the differential mortality for each occupational group in such a way that the total score is a suitable controlling factor and the differential mortality component of the score can be estimated efficiently. In practice there is no difficulty provided the total score is defined as the difference between logit mortality rate of a worker at a given age and the logit mortality rate of all workers of similar age, sex, and birth cohort (table 3).

\section{Application of the new controlling factor}

The data relating to 21880 male and 6082 female workers were first divided into 80 cohorts by cross classification of four obvious factors-namely: sex (two levels), hire age (five levels), hire dates (four levels), and duration of employment (two levels). The 80 cohorts and nine occupational groups were then used to estimate job related mortality risks by the method described in the appendix. Finally, five levels of differential mortality for each job title were defined and added to the obvious controlling factors to produce 400 instead of 80 cohorts. As individuals grow older their position on any differential mortality scale is bound to change. Therefore, some Hanford workers may have changed cohorts as they progressed either from hire to death (non-survivors) or from hire to the end of the follow up period (survivors). Nevertheless, this did not prevent each of the 400 cohorts being analysed by the Cox method of regression models in life tables. ${ }^{11}$

\section{Results of present analyses}

Before giving the results in their final form it may be as well to present a simple intuitive analysis to convince those who might doubt the need for complicated statistical analyses that the higher doses for survivors than non-survivors does constitute a real 
Table 4 First example of a Hanford work cohort: men hired in 1945 (25-34 years) who worked for more than four years

\begin{tabular}{|c|c|c|c|c|}
\hline \multirow[t]{2}{*}{ Dose (rems) } & \multicolumn{2}{|c|}{ State in 1955} & \multicolumn{2}{|c|}{ State in 1965} \\
\hline & $\begin{array}{l}\text { Whole } \\
\text { cohort }\end{array}$ & $\begin{array}{l}\text { Deaths } \\
\text { after } 1955\end{array}$ & $\begin{array}{l}\text { Whole } \\
\text { cohort }\end{array}$ & $\begin{array}{l}\text { Deaths } \\
\text { after } 1965\end{array}$ \\
\hline $\begin{array}{l}0.00- \\
0.01-0.07 \\
0.08-0.31 \\
0.32- \\
0.64- \\
1.28- \\
2.56- \\
5.12- \\
10.24- \\
>20.48 \\
\text { Total } \\
\text { Mean dose }\end{array}$ & $\begin{array}{r}191 \\
73 \\
123 \\
145 \\
164 \\
101 \\
9 \\
0 \\
0 \\
0 \\
806 \\
0 \cdot 560\end{array}$ & $\begin{array}{c}41 \\
19 \\
24 \\
23 \\
25 \\
15 \\
0 \\
0 \\
0 \\
0 \\
147 \\
0 \cdot 440\end{array}$ & $\begin{array}{c}177 \\
68 \\
118 \\
135 \\
159 \\
97 \\
9 \\
0 \\
0 \\
0 \\
763 \\
0.569\end{array}$ & $\begin{array}{c}27 \\
14 \\
19 \\
13 \\
20 \\
11 \\
0 \\
0 \\
0 \\
0 \\
104 \\
0.456\end{array}$ \\
\hline
\end{tabular}

Table 5 Second example of a Hanford work cohort: men hired in 1945 (45-54 years) who worked for more than four years

\begin{tabular}{|c|c|c|c|c|}
\hline \multirow[t]{2}{*}{ Dose (rems) } & \multicolumn{2}{|c|}{ State in 1955} & \multicolumn{2}{|c|}{ State in 1965} \\
\hline & $\begin{array}{l}\text { Whole } \\
\text { cohort }\end{array}$ & $\begin{array}{l}\text { Deaths } \\
\text { after } 1955\end{array}$ & $\begin{array}{l}\text { Whole } \\
\text { cohort }\end{array}$ & $\begin{array}{l}\text { Deaths } \\
\text { after } 1965\end{array}$ \\
\hline $\begin{array}{l}0.00 \\
0.01-0.07 \\
0.08-0.31 \\
0.32- \\
0.64- \\
1.28- \\
2.56- \\
5 \cdot 12- \\
10 \cdot 24- \\
>20.48 \\
\text { Total } \\
\text { Mean dose }\end{array}$ & $\begin{array}{r}24 \\
22 \\
175 \\
122 \\
83 \\
40 \\
16 \\
6 \\
0 \\
0 \\
388 \\
0 \cdot 817\end{array}$ & $\begin{array}{c}21 \\
15 \\
58 \\
93 \\
57 \\
30 \\
11 \\
3 \\
0 \\
0 \\
288 \\
0 \cdot 761\end{array}$ & $\begin{array}{c}15 \\
12 \\
36 \\
85 \\
71 \\
36 \\
10 \\
8 \\
7 \\
3 \\
283 \\
1.613\end{array}$ & $\begin{array}{r}12 \\
6 \\
25 \\
57 \\
41 \\
24 \\
8 \\
4 \\
4 \\
1 \\
182 \\
1 \cdot 403\end{array}$ \\
\hline
\end{tabular}

problem. To this end two of the original 80 cohorts are shown in tables 4 and 5 as though they were the result of a designed experiment-that is, both the deaths and the distribution of cumulative dose at a given time are shown, thus making it possible to see that the death rate is reduced by high dose. The corresponding sophisticated analysis, with only statistical control for the four obvious factors mentioned above, is contained in table 6. Again there is a negative association between dose and mortality whose high significance can be seen in two summary t-valves.

The reason for having two summary statistics is as follows: in any analysis of dose response the dose weighted statistic is an obvious choice. When, however, the Hanford radiation doses were grouped on an approximately logarithmic scale the dose distribution was regular (table 6). Therefore, on a linear scale of dose the distribution would be very skew, and thus allow any dose weighted statistic to be unduly affected by a small number of workers with very high doses. Some critics have implied that
Table 6 Comparing all deaths with survivors after control for obvious factors only*

\begin{tabular}{ccll}
\hline Dose (rems) & Observed & Expected $\dagger$ & t-value \\
\hline 0.00 & 1060 & 959.0 & +4.03 \\
$0.01-0.07$ & 555 & 561.8 & -0.32 \\
$0.08-0.31$ & 869 & 829.2 & +1.58 \\
$0.32-$ & 647 & 650.1 & -0.14 \\
$0.64-$ & 689 & 703.7 & -0.62 \\
$1 \cdot 28-$ & 530 & 567.6 & -1.79 \\
$2 \cdot 56-$ & 231 & 263.7 & -2.17 \\
$5 \cdot 12-$ & 150 & 163.7 & $-1 \cdot 13$ \\
10.24 & 96 & 113.8 & -1.74 \\
$>20.48$ & 112 & 126.4 & -1.36 \\
Summary & & Rank weighted -5.95 \\
t-values & & Dose weighted -3.04 \\
\hline
\end{tabular}

*Obvious factors $=$ sex, age at hire, years worked, and year of hire. †Expected calculated from survivors.

Table 7 Comparing all deaths with survivors after control for job related mortality risks* in addition to obvious factors $\dagger$

\begin{tabular}{ccll}
\hline Dose (rems) & Observed & Expected $\ddagger$ & t-value \\
\hline 0.00 & 1060 & 999.9 & +2.42 \\
$0.01-0.07$ & 555 & 570.0 & -0.72 \\
$0.08-0.31$ & 869 & 836.1 & +1.32 \\
$0.32-$ & 647 & 652.7 & -0.25 \\
$0.64-$ & 689 & 689.9 & -0.04 \\
$1.28-$ & 530 & 553.2 & -1.14 \\
$2.56-$ & 231 & 253.6 & -1.55 \\
$10.24-$ & 96 & 107.2 & -1.15 \\
$>20.48$ & 112 & 119.9 & -0.79 \\
& & Rank weighted -3.68 \\
Summary & & Dose weighted -1.94 \\
t-values & &
\end{tabular}

*See text.

†See table 6.

$\ddagger$ Expected calculated from survivors.

this is the sole reason for the controversial MSK results. ${ }^{6}$ Therefore, a rank weighted statistic which is much less affected by extreme values is shown alongside the dose weighted statistic. A further reason for having both statistics is because comparisons between them should show whether the dose response is likely to be linear-that is, the dose weighted statistic has the higher value-or curvilinear - that is, the rank weighted statistic has the higher value.

\section{Effect of adding differential mortality to the usual controlling factors}

Table 7 shows the effect of adding five levels of differential mortality to the obvious controlling factors and table 8 shows a similar table with (B) cancers as the test group. Compared with table 6 the two summary statistics have low values. There still remains, however, a significant negative association with dose. For (A) cancers there is a positive association with dose (table 9) but this achieves statistical 
Table 8 Comparing (B) cancers with survivors after control for job risks* and obvious factors*

\begin{tabular}{clll}
\hline Dose (rems) & Observed & Expected $\dagger$ & $t$-value \\
\hline 0.00 & 96 & 83.7 & +1.71 \\
$0.01-0.07$ & 39 & 45.0 & -1.00 \\
$0.08-0.31$ & 62 & 66.3 & -0.60 \\
$0.32-$ & 57 & 49.3 & +1.23 \\
$0.64-$ & 53 & 54.1 & -0.17 \\
$1.28-$ & 45 & 42.2 & +0.49 \\
$2.56-$ & 21 & 19.1 & +0.47 \\
$5.12-$ & 7 & 12.7 & -1.70 \\
$10.24-$ & 6 & 8.3 & -0.83 \\
$>20.48$ & 4 & 9.4 & -1.93 \\
& & & Rank weighted -2.33 \\
Summary & & Dose weighted -2.69 \\
t-values & \multicolumn{3}{l}{} \\
\hline
\end{tabular}

*See tables 6 and 7.

†Expected calculated from survivors.

Table 9 Comparing cancers of radiosensitive tissues with survivors after control for job risks* and obvious factors* with no allowance for latency or age effect

\begin{tabular}{cccc}
\hline Dose (rems) & Observed & Expected $\dagger$ & t-value \\
\hline 0.00 & 112 & 119.0 & -0.79 \\
$0.01-0.07$ & 70 & 72.0 & -0.27 \\
$0.08-0.31$ & 102 & 104.4 & -0.27 \\
$0.32-$ & 89 & 78.9 & +1.26 \\
$0.64-$ & 94 & 88.6 & +0.64 \\
$1.28-$ & 70 & 80.4 & -1.33 \\
$2 \cdot 56-$ & 39 & 38.0 & +0.18 \\
$5 \cdot 12-$ & 28 & 25.0 & +0.65 \\
$10 \cdot 24$ & 17 & 17.6 & -0.14 \\
$>20.48$ & 22 & 19.2 & +0.71 \\
Summary & & Rank weighted +0.95 \\
t-values & & Dose weighted +0.77
\end{tabular}

* See tables 6 and 7

†Expected calculated from survivors.

Table 10 Comparing cancers of radiosensitive tissues with survivors after control for job risks* and obvious factors* with allowance for latency only $\dagger$ and no age effect

\begin{tabular}{cccc}
\hline Dose (rems) & Observed & Expected $\dagger$ & t-value \\
\hline 0.00 & 105 & 113.4 & -0.98 \\
$0.01-0.07$ & 66 & 71.1 & -0.68 \\
$0.08-0.31$ & 99 & 105.9 & -0.77 \\
$0.32-$ & 96 & 78.8 & +2.16 \\
$0.64-$ & 77 & 79.5 & -0.32 \\
$1.28-$ & 52 & 56.8 & -0.71 \\
$2.56-$ & 33 & 27.8 & +1.07 \\
$5.12-$ & 20 & 17.6 & +0.61 \\
$10.24-$ & 17 & 13.5 & +1.02 \\
$>20.48$ & 7 & 7.7 & -0.26 \\
& & & Rank weighted +1.76 \\
Summary & & Dose weighted +0.76 \\
t-values & & \multicolumn{2}{c}{} \\
\hline
\end{tabular}

* See tables 6 and 7

†Allowance for latency by discarding last 10 years of dose. ‡Expected calculated from survivors.

significance only after making some allowance for the effects of cancer latency and exposure age (tables 10 and 11).
Table 11 Comparing cancers of radiosensitive tissues with survivors after control for job risks* and obvious factors* with allowance for latency* and age effect ${ }^{\dagger}$

\begin{tabular}{|c|c|c|c|}
\hline Dose (rems) & Observed & Expected $\dagger$ & t-value \\
\hline $\begin{array}{l}0.00 \\
0 \cdot 01-0 \cdot 07 \\
0.08-0 \cdot 31 \\
0 \cdot 32- \\
0.64- \\
1 \cdot 28- \\
2 \cdot 56- \\
5 \cdot 12- \\
10 \cdot 24- \\
>20 \cdot 48\end{array}$ & $\begin{array}{r}114 \\
95 \\
126 \\
43 \\
54 \\
47 \\
32 \\
26 \\
19 \\
16\end{array}$ & $\begin{array}{r}125 \cdot 4 \\
100 \cdot 6 \\
110 \cdot 9 \\
56 \cdot 2 \\
53 \cdot 5 \\
44 \cdot 4 \\
34 \cdot 2 \\
20 \cdot 5 \\
12 \cdot 1 \\
14 \cdot 3\end{array}$ & $\begin{array}{l}-1.31 \\
-0.67 \\
+1.70 \\
-1.93 \\
+0.08 \\
-0.44 \\
-0.41 \\
+1.31 \\
-2.09 \\
+0.52\end{array}$ \\
\hline $\begin{array}{l}\text { Summary } \\
\mathrm{t}-\mathrm{values}\end{array}$ & & $\begin{array}{l}\text { Rank weighted } \\
\text { Dose weighted }\end{array}$ & $\begin{array}{l}+2.44 \\
+1.88\end{array}$ \\
\hline
\end{tabular}

*See tables 6 and 7

tAllowance for age effect by increasing dose by $10 \%$ for each year after age 40.

$\ddagger$ Expected calculated from survivors.

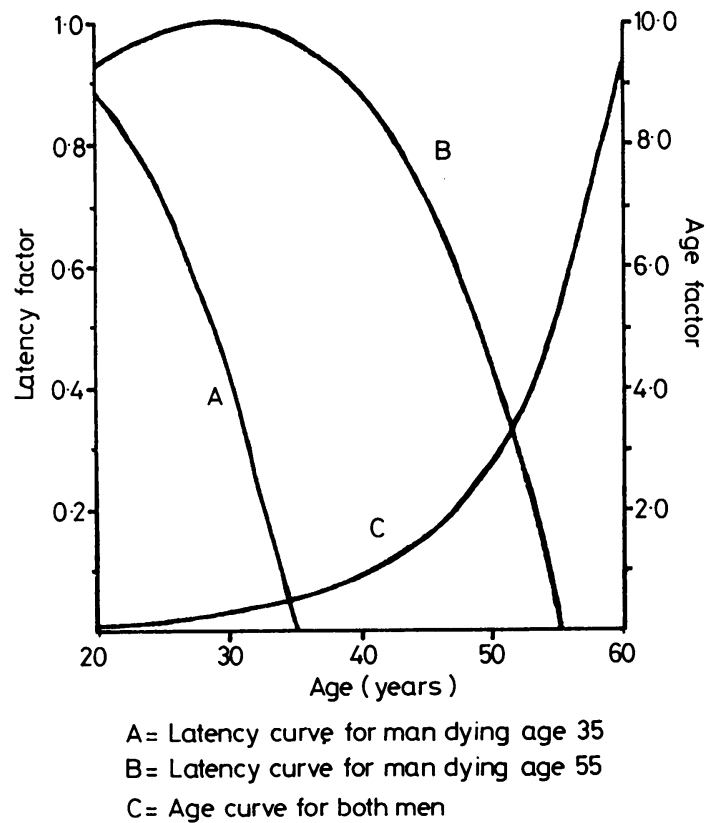

Fig 1 Effect of exposure age and latency on cancer risks of low level radiation (see MSK III).

In the original analysis of Hanford data by the method of $\mathrm{Cox}^{4}$ the effects of cancer latency and exposure age were estimated by maximum likelihood and the results were given as formulas which are graphed in fig 1 . In the present analysis there is a fixed allowance of 10 years for latency and a changing allowance for exposure age by a weight which 


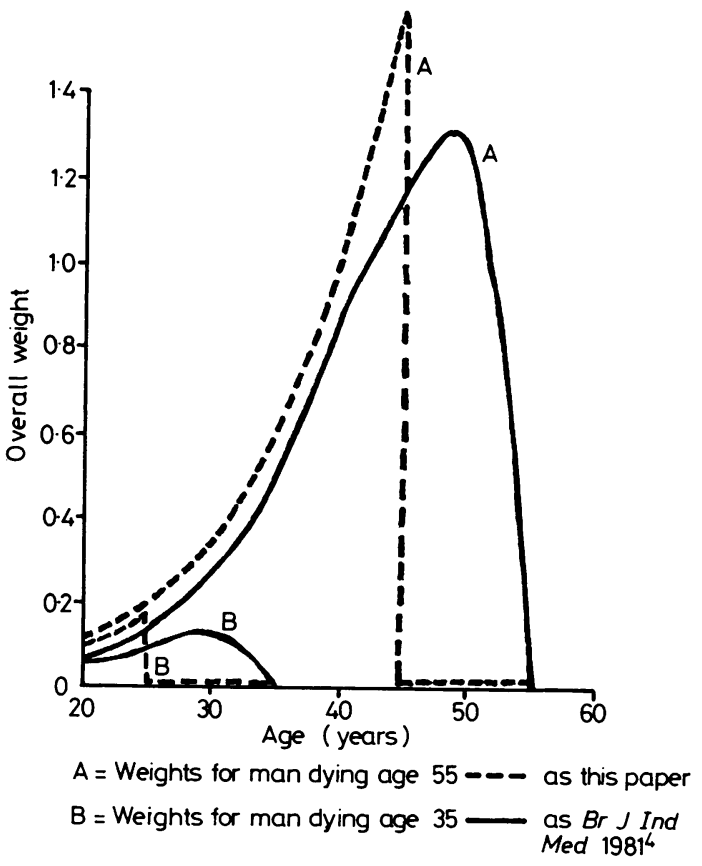

Fig 2 Dose weights of two workers: comparisons between current estimates and MSK III.

increases by $10 \%$ a year. The continuous lines in fig 2 show the dose weights derived from the two formulas for two Hanford workers, and the broken lines show the dose weights derived from the present analysis. Finally, one of the conclusions of the earlier analysis was non-linearity of dose response (with the curve obeying the square root law) which is also the impression left by the two summary statistics in tables 9 and 10 .

\section{Discussion}

The present analysis was the direct outcome of work which had shown that really dangerous jobs at Hanford were the prerogative of two groups of workers who had a reduced risk of dying from natural causes. Thus the principals had professional or technical qualifications that placed them in a high income bracket, and their assistants were skilled craftsmen who earned more than most manual workers. This selection bias, coupled with the fact that for all manual workers there was an inverse relation between differential mortality and radiation doses, made it essential to control for job related mortality risks in any study of cancer effects of the radiation.

The basic requirements for exerting this type of control were, firstly, an exact method of estimating job related mortality risks and, secondly, a grouping of over 8000 job titles into fewer than 20 groups without destroying original associations with income and danger levels. The method of job compression was described in the earlier paper and the method of risk estimation in the present one.

There are two final conclusions. The first is that screening of death benefit claims has been reasonably successful in identifying fatal cancers but for some unexplained reason the unrecognised cases include more (B) than (A) cancers and have more low than high dose cases. The second conclusion is that for cancers of radiosensitive tissue there is a definite dose response that is curvilinear with long latency and increasing effects with increasing exposure age.

\section{Appendix}

\section{EXACT ESTIMATES OF JOB RELATED MORTALITY} RISKS

Let cohorts be indexed by g, let age be indexed by a, so that $\mathrm{P}_{\mathrm{ag}}=$ probability of dying at age a in cohort g. Let workers be indexed by $i$, let $d_{i}=1$ if worker $i$ is dead, 0 otherwise. Let jobs be indexed by $\mathrm{k}$ and $\mathrm{j}$. Let $\mathbf{N}_{\text {ika }}=$ total number of years (not necessarily consecutive) for which worker $i$ has held job $k$ by time he has reached age a. Let $r_{k}(=$ health index of job $k)$ be so defined that if $S_{i a}\left(=\Sigma N_{i k a} r_{k}\right)$ is the cumulative health index score of worker $i$ by age a, then the corrected probability of dying (taking into account special risks of jobs and also any special "healthy worker effects" due to selective recruitment) is given by $\mathrm{P}_{\mathrm{ag}} \exp \left(\mathrm{S}_{\mathrm{ia}}\right) /\left[1+\mathrm{P}_{\mathrm{ag}} \exp \left(\mathrm{S}_{\mathrm{ia}}\right)-\right.$ $P_{a g}$ ], or in other words $S_{i a}$ is the change in the logit of the probability of dying. Then it can be shown by Cox's method of regression models in life tables that if the $r_{k}$ are all compared with 1 the maximum likelihood estimates of the $r_{k}$ satisfy the equations:

$$
\begin{gathered}
\sum_{\mathrm{k}} \mathrm{V}_{\mathrm{kj}} \mathrm{r}_{\mathrm{k}}=\mathrm{Y}_{\mathrm{j}} \\
\text { where } \mathrm{V}_{\mathrm{kj}}=\sum_{\mathrm{i}}\left[\sum_{\mathrm{a}=1}^{\mathrm{A}_{\mathrm{i}}} \mathrm{N}_{\mathrm{ika}} \mathrm{N}_{\mathrm{ija}} \mathrm{P}_{\mathrm{aGi}}\left(1-\mathrm{P}_{\mathrm{aG}}\right)\right] \\
\text { and } \mathrm{Y}_{\mathrm{j}}=\sum_{\mathrm{i}}\left[\mathrm{N}_{\mathrm{ijA}} \mathrm{d}_{\mathrm{i}}-\sum_{\mathrm{a}=1}^{\mathrm{A}_{\mathrm{i}}} \mathrm{N}_{\mathrm{ij} \mathrm{A}_{\mathrm{i}}} \mathrm{P}_{\mathrm{aG}}\right]
\end{gathered}
$$

and where $\mathrm{A}_{\mathrm{i}}=$ final age of worker $\mathrm{i}$ and $\mathrm{G}_{\mathrm{i}}=$ cohort of worker $\mathrm{i}$. 
Because of the complexity of the calculation to obtain the matrix $\mathrm{V}$, and the necessity to invert this, exact estimates of mortality risks can be obtained only if the maximum number of occupational groups is in the region of 20.

The cost of this analysis was borne by a grant from the United States National Institute of Occupational Safety and Health (grant No. 5 R01 08 00929-02).

\section{References}

' Mancuso TF, Stewart AM, Kneale GW. Hanford I: radiation exposures of Hanford workers, dying from cancer and other causes. Health Physics 1977;33:369-84.

${ }^{2}$ Kneale GW, Mancuso TF, Stewart AM. Hanford IIA: reanalysis of data relating to the Hanford study of the cancer risks of radiation workers. In: Late biological effects of ionizing radiation. Vol 1. Vienna: International Atomic Energy Authority, 1978:387-410.

'Stewart AM, Mancuso TF, Kneale GW. Hanford IIB: the Hanford data - a reply to recent criticisms. Ambio 1980;9:66-73.
${ }^{4}$ Kneale GW, Mancuso TF, Stewart AM. Hanford radiation study III: a cohort study of the cancer risks from radiation to workers at Hanford (1944-77 deaths) by the method of regression models in life-tables. Br J Ind Med 1981;38:156-66.

5 International Commission on Radiation Protection. Recommendations of the International Commission of Radiological Protection. (Publication No 26.) Oxford and New York: Pergamon Press, 1977.

- Marks S, Gilbert ES, Breitenstein BD. Cancer mortality in Hanford workers. In: Late biological effects of ionizing radiation. Vol 1. Vienna: International Atomic Energy Authority, 1978:369-84.

' Hutchison GB, MacMahon B, Jablon S, Land CE. Review of a report by Mancuso, Stewart, and Kneale of radiation exposure of Hanford workers. Health Physics 1979;37:207-220.

'Darby SC, Reissland JA. Low levels of ionizing radiation and cancer-are we underestimating the risk? Journal of the Royal Statistical Society 1981;144:300-14.

${ }^{9}$ International Commission on Radiation Protection. Radiosensitivity and spatial distribution of dose. (Publication No 14.) Oxford and New York: Pergamon Press, 1969.

${ }^{10}$ Kneale GW, Mancuso TF, Stewart AM. Identification of occupational mortality risks for Hanford workers. $\mathrm{Br} J$ Ind Med 1984;41:6-8.

" Cox DR. Regression models in life-tables. Journal of the Royal Statistical Society 1972;134:187-219. 